\title{
OPEN Chemical composition and biological activity of Peucedanum dhana A. Ham essential oil
}

\author{
Sarunpron Khruengsai ${ }^{1}$, Teerapong Sripahco ${ }^{1}$, Narawadee Rujanapun ${ }^{2}$, \\ Rawiwan Charoensup ${ }^{2,3}$ \& Patcharee Pripdeevech ${ }^{1,4} \llbracket$
}

The essential oil was extracted from Peucedanum dhana A. Ham, which grows in Thailand, using a Clevenger apparatus, resulting in an oil yield of $0.76 \% \mathrm{w} / \mathrm{w}$. Forty-two compounds were identified using gas chromatography-mass spectrometry. The major compounds were trans-piperitol (51.23\%), $\beta$-pinene (11.72\%), o-cymene (11.12\%), $\gamma$-terpinene $(9.21 \%)$, and limonene (4.91\%). The antimicrobial activity of the $P$. dhana essential oil was investigated by measuring the inhibition zone diameter, minimum inhibitory concentration (MIC), and minimum microbicidal concentration (MMC). The inhibition zone diameters of $P$. dhana essential oil $(1000 \mu \mathrm{g} / \mathrm{mL})$ against tested pathogens ranged from 10.70 to $40.80 \mathrm{~mm}$. Significant antimicrobial activity against tested pathogens was obtained, with MIC and MMC values of $62.50-250 \mu \mathrm{g} / \mathrm{mL}$ and $250-1000 \mu \mathrm{g} / \mathrm{mL}$, respectively. Escherichia coli, Pseudomonas aeruginosa, and Enterobacter aerogenes exposed to $P$. dhana essential oil at the MIC were analysed by flow cytometry using propidium iodide (PI) and SYTO9 to assess membrane integrity compared to trans-piperitol and $\beta$-pinene. After $24 \mathrm{~h}$, treatments with trans-piperitol resulted in the most significant cell membrane alteration and depolarization followed by $P$. dhana essential oil and $\beta$-pinene, respectively. It was demonstrated that the $P$. dhana essential oil presented antibacterial action against $E$. coli, $P$. aeruginosa, and $E$. aerogenes. The antioxidant activity of $P$. dhana essential oil was measured using 2,2-diphenyl-2-picrylhydrazyl (DPPH) and 2,2-azinobis(3-ethylbenzothiazoline6-sulfonic acid) diammonium (ABTS) scavenging activity assays. The $\mathrm{IC}_{50}$ values obtained from the DPPH and ABTS methods were 9.13 and $9.36 \mathrm{mg} / \mathrm{mL}$, respectively. The cytotoxic effect of $P$. dhana oil was tested against human colonic adenocarcinoma (SW480), human lung adenocarcinoma (A549), cervical cancer (Hela), and murine fibroblast (3T3L1) cells using the 3-(4,5-dimethylthiazol2-yl)-2,5-diphenyltetrazolium bromide (MTT) assay. The essential oil had cytotoxicity against all cancer cells, with significant cytotoxicity towards SW480 cells. As a control experiment, two pure compounds-trans-piperitol and $\beta$-pinene, were also tested for their antimicrobial, antioxidant, and cytotoxic activity. Both compounds showed varied activity in all assays. The results indicate that $P$. dhana essential oil could be used as a source of functional ingredients in food and pharmaceutical applications.

The genus Peucedanum belongs to the Apiaceae family and is composed of more than 120 species $^{1}$. Most species are widely cultivated in Europe, Asia, and Africa ${ }^{1}$. According to the ethnopharmacological history of this genera, several species were widely used as traditional medicines for cough, sore throat, cold, headache, angina, asthma, cramps, epilepsy, gastrointestinal disorders, rheumatism, gout, and cardiovascular disease ${ }^{2}$. Some species were also used as chemopreventive and antifebrile agents ${ }^{1}$. Moreover, some species were reported to possess antimicrobial, antifungal, antioxidant, anti-inflammatory, and anticancer properties ${ }^{1}$. Previous phytochemical studies on Peucedanum indicated the presence of several bioactive compounds such as coumarins, polyphenols, amines, glycosides, flavonoids, phenolic acids, and terpenes ${ }^{1}$.

\footnotetext{
${ }^{1}$ School of Science, Mae Fah Luang University, Chiang Rai 57100, Thailand. ${ }^{2}$ Medicinal Plants Innovation Center of Mae Fah Luang University, Chiang Rai 57100, Thailand. ${ }^{3}$ School of Integrative Medicine, Mae Fah Luang University, Chiang Rai 57100, Thailand. ${ }^{4}$ Center of Chemical Innovation for Sustainability (CIS), Mae Fah Luang University, Chiang Rai 57100, Thailand. ${ }^{\circledR}$ email: patcharee.pri@mfu.ac.th
} 
Various Peucedanum species produced essential oils that were reported as expectorants, sedatives, diuretics, diaphoretics, and stomachic agents ${ }^{1}$. Their essential oils also displayed biological and pharmacological activities ${ }^{1}$. The essential oils of different Peucedanum species are composed of monoterpenes and sesquiterpene hydrocarbons, oxygenated sesquiterpenes, aliphatic alcohols, and esters ${ }^{1}$. For example, $\alpha$-pinene $(4.0-38.7 \%)$ was the major compound in essential oils from $P$. officinale, $P$. alsaticum, $P$. austriacum, $P$. oreoselinum, P. longifolium, and P. cervaria ${ }^{3}$. Limonene (44.1-82.4\%) and $\alpha$-pinene (4.0-11\%) were the major compounds from P. oreoselinum essential oil ${ }^{4}$, while other monoterpenes or sesquiterpenes were reported in other species such as $P$. ruthenicum M. Bieb. and P. paniculatum ${ }^{1}$.

The P. dhana A. Ham is a plant species in the Peucedanum genus and is considered a rare herb ${ }^{1,2,5-7}$. It is a glabrous perennial tree with small yellow flowers and is calyx-teeth obsolete. It is beige with short or long hairs on the surface and a waxy coating. This plant was reported to have high medicinal value. Its roots were used as a tonic that promotes sexual desire ${ }^{8}$ and its fruits produce essential oils ${ }^{9}$. Although essential oils from other species of the Peucedanum genus are well studied, the chemical composition and the antimicrobial and antioxidant activities of essential oils from $P$. dhana are rarely explored. Therefore, the present study aims to investigate the chemical composition of essential oil extracted from P. dhana fruits and to evaluate the antimicrobial, antioxidant, and cytotoxic activities as a function of the composition.

\section{Results}

Chemical composition of P. dhana essential oil. The essential oil of $P$. dhana fruits was obtained by hydrodistillation with a yield of $0.76 \% \mathrm{w} / \mathrm{w}$ based on the dry weight. As presented in Table 1, 42 volatile compounds were identified, which represent $99.87 \%$ of the oil. Trans-piperitol, $\beta$-pinene, and o-cymene were the major volatile compounds of the $P$. dhana essential oil. These results showed there are over $98.2 \%$ monoterpene hydrocarbons in P. dhana essential oil.

Antimicrobial activity. The antimicrobial activity of $P$. dhana essential oil was evaluated against seven pathogenic microorganisms, using disc diffusion and broth microdilution methods. The zone of inhibition diameter, MIC, and MMC values of the P. dhana essential oil and chloramphenicol (control) for the tested microorganisms are shown in Table 2. The zone of inhibition diameter of the $P$. dhana essential oil for all microbial strains was similar to those obtained from the positive control. The MIC for the bacterial pathogens ranged from 62.50 to $250 \mu \mathrm{g} / \mathrm{mL}$, whereas the MIC for fungus was $125 \mu \mathrm{g} / \mathrm{mL}$. The data obtained from the disc diffusion method indicated that $P$. aeruginosa ATCC 27853 was the most sensitive (inhibition zone diameter of $40.80 \mathrm{~mm}$ ) to $1000 \mu \mathrm{g} /$ $\mathrm{mL}$ of $P$. dhana essential oil compared to other tested pathogens, which ranged from 10.70 to $19.60 \mathrm{~mm}$. P. dhana essential oil had the lowest MIC value $(62.50 \mu \mathrm{g} / \mathrm{mL})$ for all Gram-negative bacterial pathogens and high MIC values for Gram-positive bacteria and fungus, which ranged from 125 to $500 \mu \mathrm{g} / \mathrm{mL}$. The lowest MMC value was $250 \mu \mathrm{g} / \mathrm{mL}$ for $P$. aeruginosa ATCC 27853, while the highest MMC value was $1000 \mu \mathrm{g} / \mathrm{mL}$ for $S$. aureus ATCC 25923. The antimicrobial activity of trans-piperitol and $\beta$-pinene pure compounds is depicted in Table 3 . The zone diameter against the pathogens was $13.30-26.56 \mathrm{~mm}$ and $8.62-9.39 \mathrm{~mm}$, for $1000 \mu \mathrm{g} / \mathrm{mL}$ of trans-piperitol and $\beta$-pinene, respectively. Trans-piperitol showed lower MIC and MMC values than those obtained from $\beta$-pinene. The results showed that the tested pathogens were more susceptible to trans-piperitol than $\beta$-pinene.

Flow cytometric viability measurement. Flow cytometric analysis of membrane integrity with SYTO9/ PI dual staining demonstrated a unique fluorescence pattern correlated to the degree of membrane damage. Flow cytometric plots of all treated bacteria are shown in Fig. 1. Cell membrane viability of all treated bacteria is demonstrated in Fig. 2. For E. coli, after a $24 \mathrm{~h}$ incubation, the highest percentage of dead bacteria $(37.37 \%$ cell death) was seen with chloramphenicol followed by trans-piperitol (25.54\% cell death), $\beta$-pinene $(22.69 \%$ cell death), and $P$. dhana essential oil (20.14\% cell death). For $P$. aeruginosa, after a $24 \mathrm{~h}$ incubation, the highest percentage of dead bacteria was also seen with chloramphenicol (53.56\% cell death), followed by trans-piperitol ( $24.77 \%$ cell death), P. dhana essential oil ( $16.04 \%$ cell death), and $\beta$-pinene ( $15.34 \%$ cell death). For E. aerogenes, after a $24 \mathrm{~h}$ incubation, the highest percentage of death was seen with chloramphenicol $(94.86 \%$ cell death), followed by trans-piperitol (76.25\% cell death), P. dhana essential oil (65.81\% cell death), and $\beta$-pinene $(65.66 \%$ cell death).

Antioxidant activity. The antioxidant activity of $P$. dhana essential oil was investigated using DPPH and ABTS-scavenging assays. Results of the antioxidant activity of $P$. dhana essential oil and Trolox are shown as $\mathrm{IC}_{50}$ values (Table 4). The $\mathrm{IC}_{50}$ values of $P$. dhana essential oil were $9.13 \pm 0.11 \mathrm{mg} / \mathrm{mL}$ and $9.36 \pm 0.21 \mathrm{mg} / \mathrm{mL}$ using the DPPH and ABTS assays, respectively. These values are significantly higher than those from Trolox using $\mathrm{DPPH}(0.66 \pm 0.04 \mathrm{mg} / \mathrm{mL})$ and ABTS $(0.78 \pm 0.04 \mathrm{mg} / \mathrm{mL})$ assays. The antioxidant activity of trans-piperitol and $\beta$-pinene is also reported in Table $4 . \mathrm{IC}_{50}$ values of trans-piperitol were $14.76 \pm 0.15 \mathrm{mg} / \mathrm{mL}$ and $14.98 \pm 0.24 \mathrm{mg} /$ $\mathrm{mL}$ using the DPPH and ABTS assays, respectively. Meanwhile, $\mathrm{IC}_{50}$ values of $\beta$-pinene were $15.45 \pm 0.25 \mathrm{mg} / \mathrm{mL}$ and $15.56 \pm 0.61 \mathrm{mg} / \mathrm{mL}$ using the DPPH and ABTS assays, respectively.

Cytotoxicity. The cytotoxic activity of $P$. dhana oil is shown in Table 5 as $\mathrm{IC}_{50}$ values. The $\mathrm{IC}_{50}$ values obtained from $P$. dhana essential oil were $56.63 \pm 0.11 \mu \mathrm{g} / \mathrm{mL}, 51.67 \pm 0.23 \mu \mathrm{g} / \mathrm{mL}, 18.24 \pm 0.11 \mu \mathrm{g} / \mathrm{mL}$, and $961.36 \pm 0.11 \mu \mathrm{g} /$ $\mathrm{mL}$ for Hela, A549, SW480, and 3T3L1 cells, respectively. Meanwhile, the $\mathrm{IC}_{50}$ values obtained from doxorubicin were $0.55 \pm 0.21 \mu \mathrm{g} / \mathrm{mL}, 0.46 \pm 0.16 \mu \mathrm{g} / \mathrm{mL}, 0.34 \pm 0.13 \mu \mathrm{g} / \mathrm{mL}$, and $876.34 \pm 0.16 \mu \mathrm{g} / \mathrm{mL}$ for Hela, A549, SW480, and 3T3L1 cells, respectively. The $\mathrm{IC}_{50}$ values obtained from trans-piperitol were $7.07 \pm 0.67 \mu \mathrm{g} / \mathrm{mL}$, $7.76 \pm 0.35 \mu \mathrm{g} / \mathrm{mL}, 65.56 \pm 0.13 \mu \mathrm{g} / \mathrm{mL}$, and $73.30 \pm 0.23 \mu \mathrm{g} / \mathrm{mL}$ for Hela, A549, SW480, and 3T3L1 cells, respectively. Meanwhile $\mathrm{IC}_{50}$ values obtained from $\beta$-pinene were $>1000 \mu \mathrm{g} / \mathrm{mL}$ for all cells. 


\begin{tabular}{|c|c|c|c|c|c|}
\hline \multirow[b]{2}{*}{ Compound } & \multicolumn{2}{|l|}{ DB1 } & \multicolumn{2}{|l|}{ DB5 } & \multirow[b]{2}{*}{$\%$ area } \\
\hline & $\mathbf{R I}^{\mathbf{a}}$ & $\mathbf{R I}^{\mathbf{b}}$ & $\mathbf{R I}^{\mathbf{a}}$ & $\mathbf{R I}^{\mathbf{b}}$ & \\
\hline Heptanal & 887 & 880 & 911 & 901 & $t^{c}$ \\
\hline Tricyclene & 928 & 921 & 928 & 921 & $\mathrm{t}$ \\
\hline Artemisia triene & & & 931 & 923 & $\mathrm{t}$ \\
\hline a-Thujene & 932 & 925 & 934 & 924 & $\mathrm{t}$ \\
\hline a-Pinene & 941 & 934 & 940 & 932 & $0.91 \pm 0.41$ \\
\hline Camphene & 954 & 947 & 954 & 946 & $0.11 \pm 0.21$ \\
\hline Benzadehyde & 943 & 936 & 966 & 952 & $\mathrm{t}$ \\
\hline Sabinene & 974 & 967 & 979 & 969 & $0.11 \pm 0.10$ \\
\hline$\beta$-Pinene & 980 & 973 & 983 & 979 & $11.72 \pm 0.41$ \\
\hline cis-meta-mentha-2,8-diene & & & 991 & 987 & $\mathrm{t}$ \\
\hline Myrcene & 990 & 983 & 996 & 990 & $0.22 \pm 0.13$ \\
\hline Dehydroxy-trans-linalool oxide & & & 1002 & 992 & $\mathrm{t}$ \\
\hline Yomogi alcohol & 994 & 987 & 1007 & 999 & $1.34 \pm 0.22$ \\
\hline$\delta$-2-Carene & 1014 & 1007 & 1014 & 1001 & $\mathrm{t}$ \\
\hline a-Terpinene & 1017 & 1010 & 1020 & 1014 & $\mathrm{t}$ \\
\hline o-Cymene & 1019 & 1012 & 1028 & 1022 & $11.12 \pm 0.62$ \\
\hline Limonene & 1030 & 1023 & 1031 & 1024 & $4.91 \pm 0.44$ \\
\hline$\gamma$-Terpinene & 1057 & 1050 & 1061 & 1054 & $9.21 \pm 0.33$ \\
\hline trans-Arbusculone & & & 1073 & 1066 & $2.44 \pm 0.36$ \\
\hline Terpinolene & 1086 & 1079 & 1091 & 1086 & $\mathrm{t}$ \\
\hline Linalool & 1093 & 1086 & 1103 & 1095 & $0.12 \pm 0.11$ \\
\hline Pinocarvone & 1147 & 1140 & 1161 & 1160 & $\mathrm{t}$ \\
\hline Borneol & 1160 & 1153 & 1167 & 1165 & $\mathrm{t}$ \\
\hline Neoiso-isopulegol & & & 1168 & 1167 & $\mathrm{t}$ \\
\hline Terpinen-4-ol & 1171 & 1164 & 1179 & 1174 & $0.11 \pm 0.11$ \\
\hline a-Terpineol & 1182 & 1175 & 1193 & 1186 & $0.14 \pm 0.11$ \\
\hline cis-4-Caranone & & & 1200 & 1200 & $2.14 \pm 0.41$ \\
\hline Decanal & 1192 & 1185 & 1207 & 1201 & $0.24 \pm 0.31$ \\
\hline trans-Piperitol & 1200 & 1193 & 1217 & 1207 & $51.23 \pm 0.42$ \\
\hline Isobornyl acetate & 1278 & 1271 & 1285 & 1283 & $1.33 \pm 0.21$ \\
\hline$\beta$-Cubebene & 1359 & 1352 & 1390 & 1388 & $1.55 \pm 0.13$ \\
\hline Decyl acetate & 1399 & 1392 & 1410 & 1407 & $0.51 \pm 0.11$ \\
\hline E-Caryophyllene & 1414 & 1407 & 1417 & 1417 & $0.11 \pm 0.10$ \\
\hline$\delta$-Amorphene & 1473 & 1466 & 1519 & 1511 & $0.21 \pm 0.10$ \\
\hline a-Calacorene & 1537 & 1530 & 1539 & 1539 & $\mathrm{t}$ \\
\hline Maaliol & & & 1578 & 1566 & $\mathrm{t}$ \\
\hline 2-Ethylbutyric acid, octyl ester & & & 1581 & 1581 & $0.82 \pm 0.25$ \\
\hline cis-Dihydro-mayurone & & & 1604 & 1595 & $\mathrm{t}$ \\
\hline guaiol & 1595 & 1588 & 1615 & 1600 & $\mathrm{t}$ \\
\hline Muurola-4,10(14)-dien-1- $\beta$-ol & & & 1635 & 1630 & $\mathrm{t}$ \\
\hline$\alpha$-Muurolol & 1633 & 1626 & 1650 & 1643 & $\mathrm{t}$ \\
\hline Pogostol & & & 1657 & 1651 & $0.44 \pm 0.21$ \\
\hline \multicolumn{5}{|l|}{ Total } & $99.87 \pm 0.26$ \\
\hline
\end{tabular}

Table 1. Volatile compounds of $P$. dhana essential oil by GC-MS. ${ }^{a}$ Calculated retention indices. ${ }^{b}$ Retention indices on DB-1 and DB-5 columns from literature ${ }^{10,11}$. ${ }^{\mathrm{c}}$ Trace amount $<0.05$.

\section{Discussion}

Volatile compounds of the essential oils obtained from the Peucedanum species such as P. longifolium ${ }^{12}$, P. ruthenicum M. Bieb. ${ }^{13,14}, P$. japonicum ${ }^{1}, P$. austriacum ${ }^{1}, P$. alsaticum ${ }^{1}, P$. paniculatum L. $^{15}$, P. officinale ${ }^{16}$, $P$. galbanum ${ }^{1}$, P. cervaria ${ }^{1}, P$. verticillare ${ }^{1}$, and $P$. oreoselinum ${ }^{4}$ have also been reported. For example, the main components of the essential oil obtained from the P. longifolium is myrcene ${ }^{12}$. Camphor, 1,8-cineole and sabinene are the major compounds in $P$. ruthenicum M. Bieb. essential oil ${ }^{13,14}$. In addition, $\alpha$-pinene and $\beta$-phellandrene are the volatile compounds in $P$. japonicum, $P$. austriacum, $P$. cervaria, and $P$. alsaticum essential oils ${ }^{1}$. Moreover, $\beta$-cyclolavandulyl and $\beta$-isocyclolavandulyl esters are the major compounds in P. paniculatum L. essential oil ${ }^{15}$. Limonene and $\alpha$-pinene are the main compounds in $P$. officinale essential oil ${ }^{16}$. A significant amount of $\mathrm{p}$-cymene was found in P. galbanum, and P. ruthenicum M. Bieb. essential oils, while nerol was demonstrated to be the 


\begin{tabular}{|c|c|c|c|c|c|c|}
\hline \multirow[b]{2}{*}{ Microorganism } & \multicolumn{3}{|c|}{ Chloramphenicol } & \multicolumn{3}{|c|}{ P. dhana essential oil } \\
\hline & $\operatorname{MIC}(\mu \mathrm{g} / \mathrm{mL})$ & $\operatorname{MMC}(\mu \mathrm{g} / \mathrm{mL})$ & $\begin{array}{l}\text { Zone of inhibition diameter }(\mathrm{mm}) \\
(1000 \mu \mathrm{g} / \mathrm{mL})\end{array}$ & $\operatorname{MIC}(\mu \mathrm{g} / \mathrm{mL})$ & MMC $(\mu \mathrm{g} / \mathrm{mL})$ & $\begin{array}{l}\text { Zone of inhibition diameter }(\mathrm{mm}) \\
(1000 \mu \mathrm{g} / \mathrm{mL})\end{array}$ \\
\hline \multicolumn{7}{|l|}{ Gram-positive bacteria } \\
\hline S. aureus ATCC 25923 & $125.00^{c}$ & $500.00^{\mathrm{b}}$ & $19.10 \pm 0.01^{\mathrm{c}}$ & $250.00^{c}$ & $1000.00^{c}$ & $18.20 \pm 0.20^{\mathrm{b}}$ \\
\hline S. epidermidis ATCC 12228 & $125.00^{c}$ & $500.00^{\mathrm{b}}$ & $19.50 \pm 0.01^{\mathrm{c}}$ & $125.00^{\mathrm{b}}$ & $500.00^{\mathrm{b}}$ & $19.25 \pm 0.25^{\mathrm{b}}$ \\
\hline B. subtilis ATCC 6051 & $62.50^{\mathrm{b}}$ & $500.00^{\mathrm{b}}$ & $20.40 \pm 0.01^{\mathrm{b}}$ & $125.00^{\mathrm{b}}$ & $1000.00^{c}$ & $19.60 \pm 0.31^{\mathrm{b}}$ \\
\hline \multicolumn{7}{|l|}{ Gram-negative bacteria } \\
\hline E. coli ATCC 25922 & $62.50^{\mathrm{b}}$ & $500.00^{\mathrm{b}}$ & $10.10 \pm 0.00^{\mathrm{e}}$ & $62.50^{\mathrm{a}}$ & $500.00^{\mathrm{b}}$ & $12.90 \pm 0.20^{c}$ \\
\hline P. aeruginosa ATCC 27853 & $31.25^{\mathrm{a}}$ & $250.00^{\mathrm{a}}$ & $40.30 \pm 0.01^{\mathrm{a}}$ & $62.50^{\mathrm{a}}$ & $250.00^{\mathrm{a}}$ & $40.80 \pm 0.20^{\mathrm{a}}$ \\
\hline E. aerogenes ATCC 13048 & $62.50^{\mathrm{b}}$ & $500.00^{\mathrm{b}}$ & $19.20 \pm 0.03^{c}$ & $62.50^{\mathrm{a}}$ & $500.00^{\mathrm{b}}$ & $18.70 \pm 0.30^{\mathrm{b}}$ \\
\hline \multicolumn{7}{|l|}{ Fungus } \\
\hline C. albicans ATCC 10231 & $62.50^{\mathrm{b}}$ & $500.00^{\mathrm{b}}$ & $17.50 \pm 0.20^{\mathrm{d}}$ & $125.00^{\mathrm{b}}$ & $500.00^{\mathrm{b}}$ & $10.70 \pm 0.20^{\mathrm{d}}$ \\
\hline
\end{tabular}

Table 2. Antimicrobial activity of $P$. dhana essential oil and chloramphenicol. The data are mean \pm standard deviation. Different letters indicate significant differences $(\mathrm{p}<0.05)$.

\begin{tabular}{|c|c|c|c|c|c|c|}
\hline \multirow[b]{2}{*}{ Microorganism } & \multicolumn{3}{|l|}{ trans-Piperitol } & \multicolumn{3}{|l|}{$\beta$-Pinene } \\
\hline & $\operatorname{MIC}(\mu \mathrm{g} / \mathrm{mL})$ & $\operatorname{MMC}(\mu \mathrm{g} / \mathrm{mL})$ & $\begin{array}{l}\text { Zone of inhibition diameter }(\mathrm{mm}) \\
(1000 \mu \mathrm{g} / \mathrm{mL})\end{array}$ & $\operatorname{MIC}(\mu \mathrm{g} / \mathrm{mL})$ & MMC $(\mu \mathrm{g} / \mathrm{mL})$ & $\begin{array}{l}\text { Zone of inhibition diameter }(\mathrm{mm}) \\
(1000 \mu \mathrm{g} / \mathrm{mL})\end{array}$ \\
\hline \multicolumn{7}{|l|}{ Gram-positive bacteria } \\
\hline S. aureus ATCC 25923 & $125.00^{c}$ & $1000.00^{\mathrm{d}}$ & $13.30 \pm 0.21^{\mathrm{f}}$ & $500.00^{\mathrm{b}}$ & $1000.00^{\mathrm{b}}$ & $8.86 \pm 0.18^{\mathrm{b}}$ \\
\hline S. epidermidis ATCC 12228 & $125.00^{c}$ & $500.00^{c}$ & $15.43 \pm 0.22^{\mathrm{e}}$ & $500.00^{\mathrm{b}}$ & $1000.00^{\mathrm{b}}$ & $8.78 \pm 0.21^{\mathrm{c}}$ \\
\hline B. subtilis ATCC 6051 & $125.00^{c}$ & $1000.00^{\mathrm{d}}$ & $15.34 \pm 0.11^{\mathrm{e}}$ & $500.00^{\mathrm{b}}$ & $1000.00^{\mathrm{b}}$ & $8.62 \pm 0.11^{\mathrm{d}}$ \\
\hline \multicolumn{7}{|l|}{ Gram-negative bacteria } \\
\hline E. coli ATCC 25922 & $62.50^{\mathrm{b}}$ & $250.00^{\mathrm{b}}$ & $19.23 \pm 0.10^{c}$ & $500.00^{\mathrm{b}}$ & $1000.00^{\mathrm{b}}$ & $8.81 \pm 0.11^{\mathrm{b}}$ \\
\hline P. aeruginosa ATCC 27853 & $31.25^{\mathrm{a}}$ & $125.00^{\mathrm{a}}$ & $26.56 \pm 0.2^{1 \mathrm{a}}$ & $250.00^{\mathrm{a}}$ & $1000.00^{\mathrm{b}}$ & $9.39 \pm 0.15^{\mathrm{a}}$ \\
\hline E. aerogenes ATCC 13048 & $31.25^{\mathrm{a}}$ & $125.00^{\mathrm{a}}$ & $25.47 \pm 0.13^{\mathrm{b}}$ & $250.00^{\mathrm{a}}$ & $1000.00^{\mathrm{b}}$ & $8.83 \pm 0.14^{\mathrm{b}}$ \\
\hline \multicolumn{7}{|l|}{ Fungus } \\
\hline C. albicans ATCC 10231 & $62.50^{\mathrm{b}}$ & $250.00^{\mathrm{b}}$ & $18.86 \pm 0.12^{\mathrm{d}}$ & $500.00^{\mathrm{b}}$ & $500.00^{\mathrm{a}}$ & $8.74 \pm 0.21^{c}$ \\
\hline
\end{tabular}

Table 3. Antimicrobial activity of trans-piperitol and $\beta$-pinene. The data are mean \pm standard deviation. Different letters indicate significant differences $(\mathrm{p}<0.05)$.

major compound in $P$. verticillare fresh fruit essential oil ${ }^{1}$. It is possible to detect a diversity of terpenes, especially monoterpenes, in essential oils from plant species of the Peucedanum genus. Factors including plant age, cultivation, climatic and micro-environmental conditions, seasons, harvest times, chemotypic variation, and geography play important roles in the various chemical compositions of essential oils from plants. For example, the amounts of $\gamma$-terpinene and $\beta$-pinene in P. oreoselinum fruit essential oil increased in the presence of sunlight ${ }^{4}$. Figuérédo et al. ${ }^{16}$ reported that the amount of $\alpha$-phellandrene in $P$. officinale flowers essential oil was significantly higher than those obtained from other parts of the plant. Alavi et al. ${ }^{13}$ also reported different major compounds in the essential oils from the leaf, flower, and fruits of P. ruthenicum M. Bieb. In the essential oils extracted from the leaf, thymol and $\beta$-bisabolene were the major compounds. However, both compounds were not detected in essential oils extracted from the flowers and fruits. Moreover, the amount of thymol and $\beta$-bisabolene in the P. ruthenicum M. Bieb. leaf oil decreased as humidity increases ${ }^{3}$.

In our study, $P$. dhana essential oil inhibited the growth of microbial pathogens, especially Gram-negative bacteria, as evidenced by the MIC value of $62.50 \mu \mathrm{g} / \mathrm{mL}$. Essential oils extracted from several species, including P. longifolium ${ }^{12}$, ferulaefolium ${ }^{17}$, P. ruthenicum M. Bieb. ${ }^{18}$, P. japonicum ${ }^{19}$, P. alsaticum, and $P$. cervaria ${ }^{20}$, had antibacterial properties. For example, the essential oil extracted from P. ruthenicum M. Bieb. fruits showed antibacterial activities against $S$. aureus, S. epidermidis, and B. cereus ${ }^{13}$. According to Pirbalouti et al..$^{21}$, essential oil extracted from P. membranacea Boiss exhibited significant antibacterial activity against the Proteus vulgaris strain. However, there is no report on the antifungal activity from essential oil extracted from Peucedanum species. Our results show not only the growth reduction potential of bacterial pathogens but also antifungal activity against C. albicans. The antimicrobial activity of essential oils is mainly associated with the presence of active compounds, including monoterpenes, sesquiterpenes, and their derivatives, as reported by Burt ${ }^{22}$. Essential oils of Spanish Mentha rotundifolia ${ }^{23}$ and Ocimum canum ${ }^{24}$ are rich in piperitol and present weak antibacterial activity. In this study, trans-piperitol showed higher antimicrobial activity compared to that of $\beta$-pinene and the $P$. dhana essential oil. This result may depend on different pathogenic strains and concentrations of compounds. The strong antimicrobial activity may be explained by trans-piperitol and the synergetic effects of the major and minor compounds in the $P$. dhana essential oil ${ }^{25-27}$. It was found that the mode of action of the $P$. dhana essential 


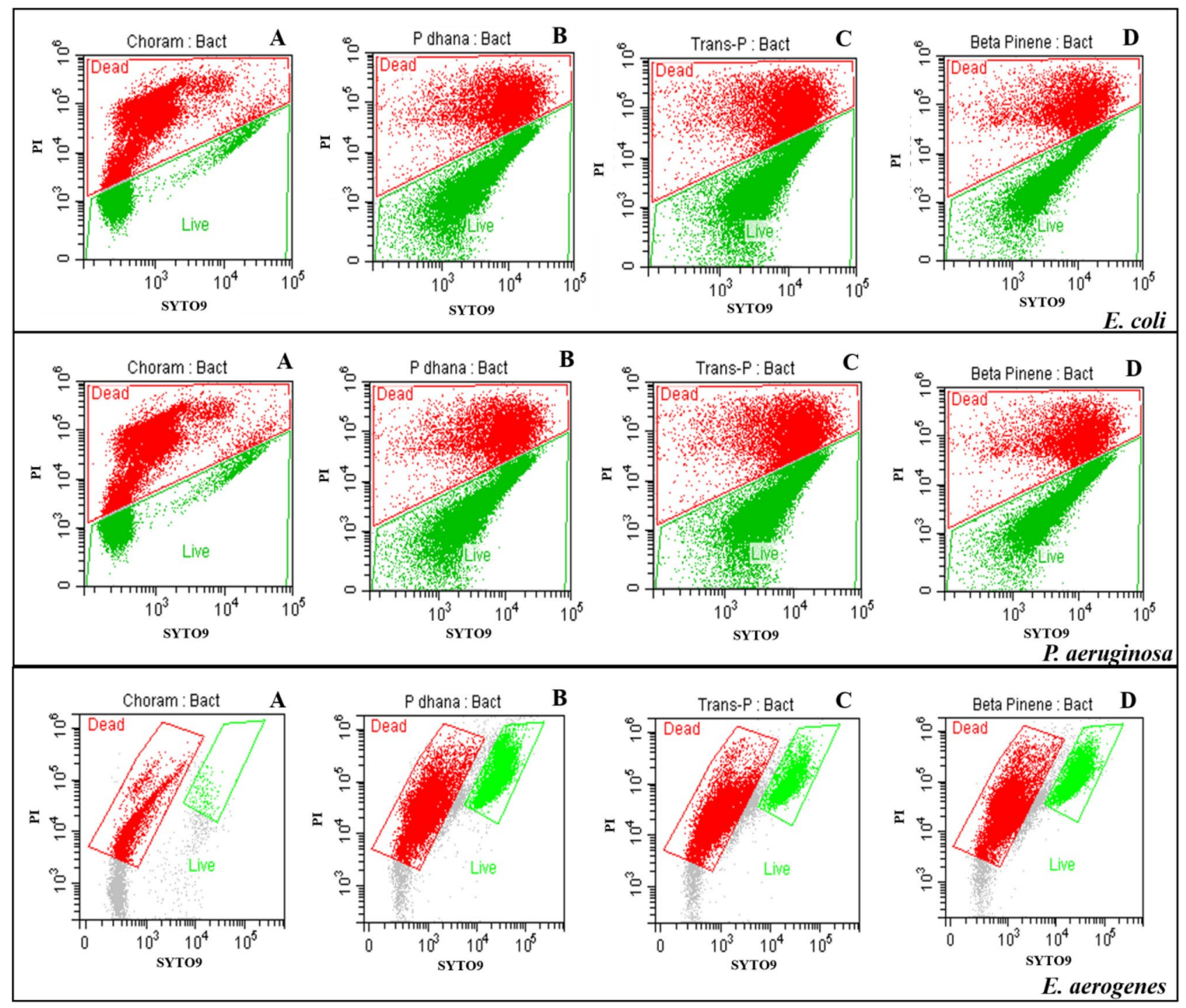

Figure 1. Flow cytometry dot plots of SYTO9 vs. PI of E. coli, P. aeruginosa, and E. aerogenes following treatment with chloramphenicol (A), P. dhana essential oil (B), trans-piperitol (C), and $\beta$-pinene (D).

oil may depend on the hydrophobicity of the functional groups in their chemical compounds. The hydrophobicity enables the partition of lipids of the bacterial cell membrane, which results in a disturbance of the cell wall and the cytoplasmic membrane and eventually leads to lysis and leakage of intracellular compounds ${ }^{28}$. In addition, Moleyar and Narasimtram ${ }^{29}$ stated the antimicrobial activity of volatile compounds in essential oils is a combined effect of direct and indirect vapor absorption on pathogenic strains through the aqueous medium. The vapor absorption on microbial pathogens was detected by changes in membrane permeability. The absorption into aqueous media was examined by solubility, volatility, and stability of their volatile compounds.

In addition, the impact of the $P$. dhana essential oil on the viability of bacterial cells and cell damage was estimated with highly sensitive fluorescence-based flow cytometric data. PI was used to intercalate a stain that cannot penetrate the healthy cells while SYTO9 was used to intercalate a stain that can penetrate all damaged and healthy cells. As a result, chloramphenicol, an antibiotic drug, showed higher antibacterial activity (from high level of PI with lysed cells) than other treatments. It was found that PI permeabilized cytoplasmic membranes and PI staining intercalated with DNA and directly damaged bacteria membrane. The metabolic activity of $E$. coli and $P$. aeruginosa cells was mostly weakened under the influence of $P$. dhana essential oil and other compounds compared to those found in E. aerogenes cells. We compared the effectiveness of two methods to determine the antibacterial effects. The results obtained from flow cytometry were not in accordance with those obtained from the resazurin assay. The observed differences between both methods suggested the presence of a sub-lethally stressed subpopulation not able to form colonies on microplates. It is additional proof that $P$. dhana essential oil in low concentrations does not cause the death of bacterial cells. Flow cytometric analysis showed that, in the presence of $P$. dhana essential oil, the observed loss of viability of bacterial strains could be correlated to membrane depolarization and membrane alteration ${ }^{30}$. In addition, trans-piperitol and $\beta$-pinene, the major compounds of $P$. dhana essential oil, possess one or several mechanisms of bacterial growth inhibition, and there 

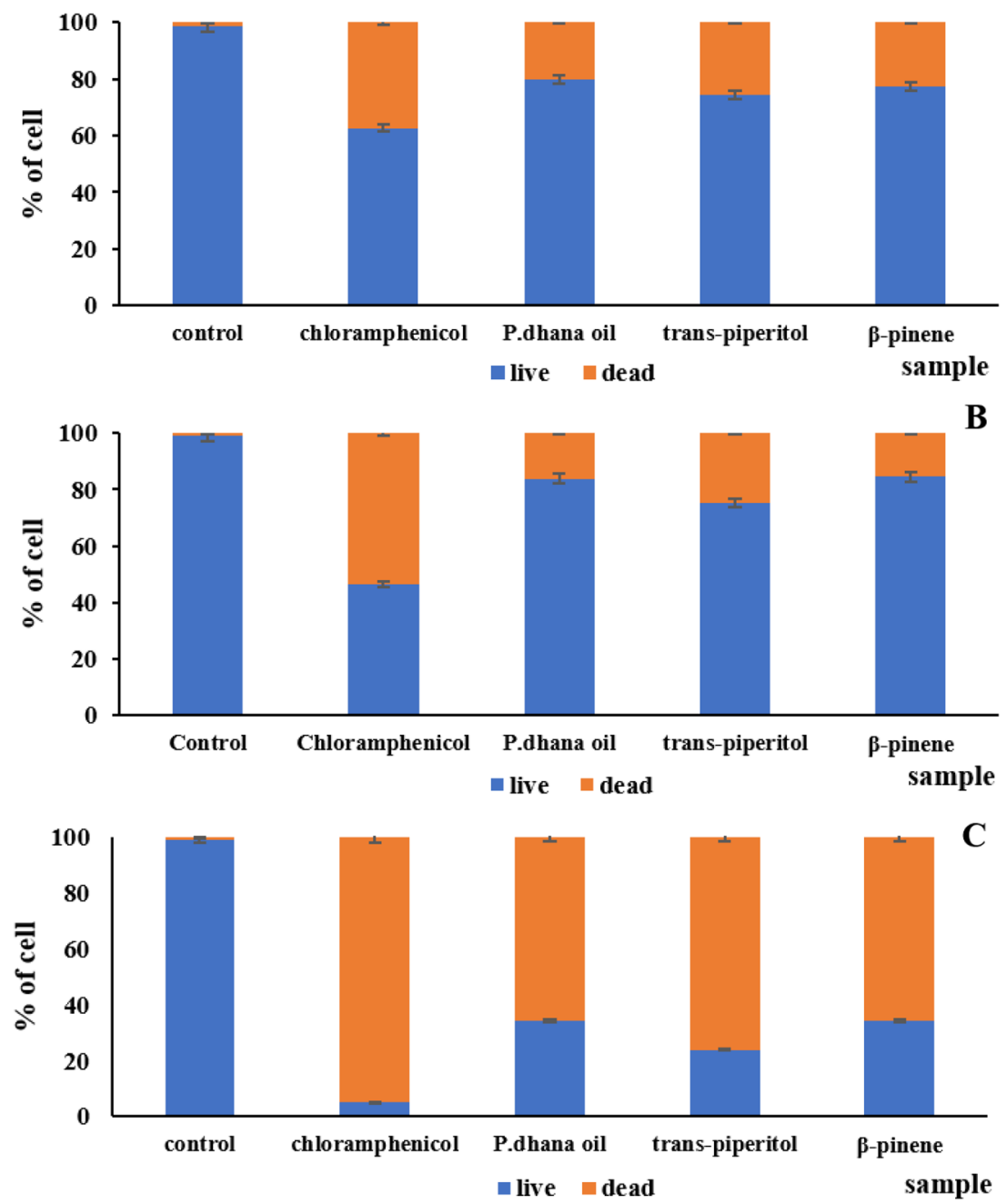

Figure 2. Percentages of bacterial cell subpopulations (lived cells and dead cells) of E. coli (A), P. aeruginosa (B), and E. aerogenes (C) following treatment with chloramphenicol, $P$. dhana essential oil, trans-piperitol, and $\beta$-pinene.

\begin{tabular}{|l|l|l|c|}
\hline \multirow{2}{*}{ Sample } & Yield & $\mathbf{I C}_{\mathbf{5 0}}(\mathbf{m g} / \mathbf{m L})$ & ABTS \\
\cline { 2 - 4 } & $(\% \mathbf{w} / \mathbf{w})$ & DPPH & $9.36 \pm 0.21^{\mathrm{d}}$ \\
\hline P. dhana essential oil & $0.76 \pm 0.21$ & $9.13 \pm 0.11^{\mathrm{d}}$ & $0.78 \pm 0.04^{\mathrm{a}}$ \\
\hline Trolox & & $0.66 \pm 0.04^{\mathrm{a}}$ & $14.98 \pm 0.24^{\mathrm{b}}$ \\
\hline trans-Piperitol & & $14.76 \pm 0.15^{\mathrm{b}}$ & $15.56 \pm 0.61^{\mathrm{c}}$ \\
\hline$\beta$-Pinene & & $15.45 \pm 0.25^{\mathrm{c}}$ & \\
\hline
\end{tabular}

Table 4. Antioxidant activity of $P$. dhana essential oil, Trolox, trans-piperitol, and $\beta$-pinene. The data are mean \pm standard deviation. Different letters indicate significant differences $(p<0.05)$.

may be synergetic effects among these components. These possible multiple targets and heterogenous effects could also describe the successive physiological states detected in this study in relation to membrane damage and depolarization. Our study confirmed the antimicrobial action of the $P$. dhana essential oil at the tested concentrations on bacterial cell membrane integrity.

The antioxidant activity of $P$. dhana essential oil are not yet reported. However, there are already a few reports about the antioxidant activity of essential oils obtained from other Peucedanum species. Normally, essential oils were evaluated as a weak antioxidant ${ }^{31}$. Tepe et al. ${ }^{32}$ found that the inhibition percentage of free radical DPPH in P. longifolium and P. palimbioides essential oils was $8.59-41.87 \%$ and $10.67-47.26 \%$, respectively. These values are lower than those of the standard butylated hydroxytoluene and butylated hydroxyanisole compounds at $93.85 \%$ 


\begin{tabular}{|l|l|c|c|l|}
\hline \multirow{2}{*}{ Cell } & \multicolumn{2}{|l|}{$\mathrm{IC}_{50}(\mu \mathrm{g} / \mathrm{mL})$} & \multicolumn{2}{l|}{} \\
\cline { 2 - 5 } & P. dhana essential oil & Doxorubicin & $7.07 \pm 0.67^{\mathrm{a}}$ & $>$-Pinene \\
\hline Hela & $56.63 \pm 0.11^{\mathrm{c}}$ & $0.55 \pm 0.21^{\mathrm{c}}$ & $7.76 \pm 0.35^{\mathrm{b}}$ & $>1000$ \\
\hline A549 & $51.67 \pm 0.23^{\mathrm{b}}$ & $0.46 \pm 0.16^{\mathrm{b}}$ & $65.56 \pm 0.13^{\mathrm{c}}$ & $>1000$ \\
\hline SW480 & $10.24 \pm 0.11^{\mathrm{a}}$ & $0.34 \pm 0.13^{\mathrm{a}}$ & $76.30 \pm 0.23^{\mathrm{d}}$ & $>1000$ \\
\hline 3T3L1 & $961.36 \pm 0.11^{\mathrm{d}}$ & $876.34 \pm 0.16^{\mathrm{d}}$ & & \\
\hline
\end{tabular}

Table 5. Cytotoxicity of $P$. dhana essential oil, doxorubicin, trans-piperitol, and $\beta$-pinene. The data are mean \pm standard deviation. Different letters indicate significant differences $(p<0.05)$.

and $94.98 \%$, respectively. Our results agreed with those from previous studies. In particular, the antioxidant activity of the $P$. dhana essential oil may be attributed to the presence of various monoterpenes like $\beta$-pinene, $\gamma$-terpinene, and limonene. $\beta$-pinene, which is a major compound in many essential oils such as turpentine oils, exhibited antioxidant activity ${ }^{33}$. Previous studies also confirmed that $\gamma$-terpinene and limonene exhibited good antioxidant activities. Thus, the total antioxidant activity of essential oil may be correlated to the antioxidant activities from the volatile compounds listed in Table 1, and not only from the major ones that have low antioxidant activity. The DPPH and ABTS assays are hydrogen atom abstraction assays. The radical scavenging abilities of chemical compounds in essential oils may be related to the bond dissociation energies (BDEs) of the compounds $^{34}$. In the case of $\gamma$-terpinene, low BDE was measured due to the abstraction of three potential allylic hydrogen atoms. As a result, hydrogens in the ring have much lower BDEs than isopropyl hydrogen. However, antioxidant activities of essential oils or pure compounds have shown less correlation between DPPH and ABTS activities. DPPH and ABTS assays were considered as complicated thermodynamic assays based on kinetic and stoichiometric effects and may also be related to complex multistep reaction mechanisms ${ }^{34}$.

Due to the cytotoxicity of essential oils, they have been applied as potential antitumor agents. This study evaluated the cytotoxicity of essential oil extracted from $P$. dhana fruits in both cancer and normal cells using an MTT assay. The $P$. dhana essential oil, trans-piperitol, $\beta$-pinene, and the positive control, doxorubicin demonstrated different cytotoxicity depending on the cells. Varied results may be related to the functional groups represented in each compound or composition. However, IC $_{50}$ values obtained from antimicrobial activity tests of $P$. dhana essential oil, suggest that the $P$. dhana oil has a moderate to strong cytotoxic effect. This result agrees with those from previous studies on essential oils from various plant species. Sylvestre et al. ${ }^{35}$ reported the $\mathrm{IC}_{50}$ values of essential oils and their corresponding cytotoxic activity. $\mathrm{IC}_{50}$ values of $10-50 \mu \mathrm{g} / \mathrm{mL}, 50-100 \mu \mathrm{g} / \mathrm{mL}$, $100-200 \mu \mathrm{g} / \mathrm{mL}$, and $200-300 \mu \mathrm{g} / \mathrm{mL}$ indicate strong, moderate, weak, and very weak cytotoxic properties. In addition, $\mathrm{IC}_{50}$ values higher than $300 \mu \mathrm{g} / \mathrm{mL}$ indicate no cytotoxicity. Considering the cytotoxic activity on the four cells tested with the MTT assay, $P$. dhana essential oil showed moderate cytotoxic activity against the Hela and A549 cells, and strong cytotoxic activity against SW480 cells. The doxorubicin, used as a positive control in this study, had strong cytotoxic activity against cancer cells. Doxorubin is considered a broad-spectrum antitumor antibiotic and is most extensively used in chemotherapy regimens for cancer patients. $\beta$-pinene, $\alpha$-pinene, and $\gamma$-terpinene are considered to be the compounds responsible for some of the cytotoxic activities ${ }^{36,37}$. However, other compounds such as limonene, $\beta$-cubebene, $\alpha$-terpineol, and camphene are previously known to have cytotoxic effects against different cells ${ }^{38}$. The molecular mechanism of the cytotoxicity of $P$. dhana essential oil may be the induction of apoptosis and necrosis. In eukaryotic cells, essential oils can induce depolarization of the mitochondrial membranes, thereby decreasing the $\mathrm{pH}$ gradient and affecting calcium, other ions, the proton pump, and the ATP pool ${ }^{39}$. Membrane fluidity also changed and became abnormally permeable, demonstrating the leakage of radicals, cytochrome c, calcium ions, and proteins. The permeabilization of the inner and outer mitochondrial membranes resulted in cell death by apoptosis and necrosis. Considering an investigation about the cytotoxic effect of Peucedanum spp. on tumor cells, Yeong et al. ${ }^{39}$ reported that the P. japonicum Thunb essential oil revealed cytotoxic activity against A549 cells with an $\mathrm{IC}_{50}$ of $0.04192 \% \mathrm{v} / \mathrm{v}$. The results obtained from this study also present the importance of $P$. dhana as an alternative herbal source of essential oil that can be used as a cytotoxic agent against cancer cells, especially in human colonic adenocarcinoma.

\section{Conclusion}

The major volatile compounds of the essential oil obtained from $P$. dhana fruits were trans-piperitol, $\beta$-pinene, and o-cymene. The $P$. dhana essential oil had strong antimicrobial activity against Gram-negative bacteria, Grampositive bacteria, and the fungus $C$. albicans. It was demonstrated using flow cytometry and specific staining that the $P$. dhana essential oil has bacteriostatic action in vitro against test bacteria at MIC, with combined effects on cell membrane alteration and depolarization. The $P$. dhana essential oil may not directly damage the bacterial outer membrane due to different dynamics of bacterial viability states from staining results. The essential oil showed antioxidant activity mainly through the inhibition of DPPH and ABTS assays and had cytotoxic effects against the tested cancer cells, especially the SW480 cells. The strong biological activity of $P$. dhana essential oil may be due to trans-piperitol and the synergistic interactions of the terpenes. Our results highlight the potential of $P$. dhana as a source of essential oil for pharmaceutical applications, such as antimicrobials and health promoters. 


\section{Materials and methods}

Chemicals and media. Anhydrous sodium sulfate, sodium carbonate, dichloromethane, chloramphenicol, $\beta$-pinene dimethylsulfoxide, DPPH, Trolox, methanol, ABTS, potassium persulfate, gallic acid, Folin-Ciocalteu reagent, gallic acid, MTT, and resazurin were purchased from Sigma-Aldrich (USA). Trans-piperitol was purchased from BioCrick (China). Dulbecco's Modified Eagle medium (DMEM) and fetal bovine serum were purchased from Gibco (USA). Sabouraud dextrose and Müller-Hinton broths were purchased from Becton, Dickinson, and Company (USA) and YM (USA), respectively.

Plant material. P. dhana A. Ham fruits were collected during their flowering stage at Thung Hua, Wang Nuea district, located in Lampang province, Northern Thailand (latitude: $19^{\circ} 23^{\prime} 75.3^{\prime \prime}$ S, longitude: $99^{\circ} 57^{\prime} 50.6^{\prime \prime}$ W, altitude: $720 \mathrm{~m}$ ) in December 2019. The collection site access was approved by Mr. Vichien Tammasorn, the farm owner. The plant was identified by taxonomist Dr. Jantrararuk Tovaranonte, head of Mae Fah Luang Botanical Garden and a voucher specimen (No. 10124) was deposited in the Mae Fah Luang Botanical Garden, Mae Fah Luang University, Chiang Rai, Thailand. Harvested plant material was dried indoors at room temperature for 2 weeks and further stored in plastic containers at room temperature until use. This study complies with relevant institutional, national, and international guidelines and legislation.

Essential oil extraction. The dried $P$. dhana fruits (500 g) were subjected to hydrodistillation for $4 \mathrm{~h}$ using a Clevenger-type apparatus (Duran West Germany). The obtained fruit essential oil was collected and combined with anhydrous sodium sulfate to remove the water. The essential oil was collected in a vial, sealed, and stored at $4{ }^{\circ} \mathrm{C}$. The essential oil yield was calculated as [mass of essential oil obtained $(\mathrm{g}) /$ mass of dry sample $\left.(\mathrm{g})\right] \times 100$. This extraction was performed three times.

Identification of chemical composition by gas chromatography-mass spectrometry (GCMS). First, the essential oil was diluted with dichloromethane $(1: 100 \mathrm{v} / \mathrm{v})$. The chemical composition of the $P$. dhana essential oil was identified using an Agilent $6890 \mathrm{~N}$ gas chromatograph connected to a mass spectrometer (Agilent 5973 network mass selective detector, Agilent Technologies, Santa Clara, CA, USA). A fused-silica capillary DB5-MS $(30 \mathrm{~m} \times 0.25 \mathrm{~mm}$ i.d., $0.25 \mu \mathrm{m})$ (J\&W Scientific, USA) was used in the system. A total of $1 \mu \mathrm{L}$ of sample was injected using a split ratio of 1:50. The oven temperature started at $60^{\circ} \mathrm{C}$, then increased to $240{ }^{\circ} \mathrm{C}$ at a rate of $3{ }^{\circ} \mathrm{C} / \mathrm{min}$. Helium (99.99\% purity) was used as the carrier gas with a flow rate of $1 \mathrm{~mL} / \mathrm{min}$. Electron impact ionization was used, with the electron energy set to $70 \mathrm{eV}$. The ion source temperature was set to $250^{\circ} \mathrm{C}$. The acquisition was performed in scan mode $(m / z 30-300)$. Quantitative analysis was performed based on the total ion count detected by the GC-MS. Compounds were identified using their retention indices and mass spectra. Retention indices were calculated using linear interpolation of the retention times of $\mathrm{C}_{9}-\mathrm{C}_{17} n$-alkanes on both the DB-1 (100\% dimethylpolysiloxane) and DB5-MS (5\% diphenyl/95\% dimethylpolysiloxane) column $(30 \mathrm{~m} \times 0.25 \mathrm{~mm}$ i.d., $0.25 \mu \mathrm{m})$ (J\&W Scientific, USA) as well as further compared to corresponding reference standard data reported by Adams ${ }^{10}$, Babushok et al. ${ }^{11}$, and the mass spectra from the W8N08 and Wiley $7 \mathrm{~N}$ libraries. Quantitative analysis of volatile compounds was performed using a relative peak area percentage on the spectra taken using an Agilent $6890 \mathrm{~N}$ gas chromatograph connected to a flame ionization detector (Agilent Technologies, Santa Clara, CA, USA). The same parameters as those used to identify the essential oil were used. The injector and detector temperatures were $250{ }^{\circ} \mathrm{C}$ and $280^{\circ} \mathrm{C}$, respectively. The experiment was performed three times.

Antimicrobial activity. Microbial strains. Seven human pathogens were used in this study including three Gram-positive bacteria: Staphylococcus aureus ATCC 25923, S. epidermidis ATCC 12228, and Bacillus cereus ATCC 11778, three Gram-negative bacteria: Escherichia coli ATCC 25922, Pseudomonas aeruginosa ATCC 27853, and Enterobacter aerogenes ATCC 13048, and one fungus: Candida albicans ATCC 10231. All bacterial strains were obtained from the Department of Medical Science, Ministry of Health, Bangkok, Thailand while the fungus C. albicans ATCC10231 was obtained from the culture collection of the Faculty of Dentistry, Khon Kaen University.

Disc diffusion test. The antimicrobial screening was conducted by a modified disc diffusion method ${ }^{27}$. All bacterial strains were sub-cultured in Müller-Hinton broth while the fungus was sub-cultured in sabouraud dextrose broth. All strains were incubated at $37^{\circ} \mathrm{C}$ for $24 \mathrm{~h}$. The turbidity of the cell suspension was measured at $600 \mathrm{~nm}$ and adjusted with broth media to reach a $0.5 \mathrm{McF}$ arland standard. The $P$. dhana essential oil, chloramphenicol, trans-piperitol, and $\beta$-pinene were prepared at a concentration of $1000 \mu \mathrm{g} / \mathrm{mL}$ in $10 \%$ dimethylsulfoxide (DMSO) and sterilized distilled water, respectively. Each bacterial strain was spread on a sterile Petri dish containing Müller-Hinton or sabouraud dextrose agar using a sterile cotton swab. Then, $30 \mu \mathrm{L}$ of each sample was dropped on a $6 \mathrm{~mm}$ diameter sterilized paper disc (Whatman, USA) and placed on a Petri dish. All bacterial plates were incubated at $37^{\circ} \mathrm{C}$ for $24 \mathrm{~h}$, while fungal plates were incubated at $28^{\circ} \mathrm{C}$ for $48 \mathrm{~h}$. The diameter of the inhibition clear zone after incubation was measured in millimetres by a Vernier caliper. 10\% DMSO and chloramphenicol were used as negative and positive controls in the same conditions as essential oil, respectively. Each experiment was carried out in triplicate.

MIC and MMC analysis. MIC values inhibiting the growth of tested pathogens were measured by a broth microdilution method according to a modified method ${ }^{27}$. The essential oil, chloramphenicol, trans-piperitol, and $\beta$-pinene at different concentrations were dissolved in 10\% DMSO and sterilized distilled water with the fol- 
lowing concentrations, respectively: $1000,500,250,125,62.50,31.25,15.62$, and $7.81 \mu \mathrm{g} / \mathrm{mL}$. A two-fold dilution procedure was used for all mixtures. The experiment was performed in sterile 96 -well microtiter plates. A combination of $10 \mu \mathrm{L}$ of microbial suspension $\left(10^{6} \mathrm{CFU} / \mathrm{mL}\right)$ of each pathogen and $0.675 \%$ resazurin were added to each well containing $50 \mu \mathrm{L}$ of sample. Müller-Hinton medium was used for bacteria, while sabouraud dextrose medium was used for the fungus. All plates were covered with a sterile cap. The bacterial plates were incubated at $37^{\circ} \mathrm{C}$ for $4 \mathrm{~h}$, while fungal plates were incubated at $28^{\circ} \mathrm{C}$ for $4 \mathrm{~h} .10 \% \mathrm{DMSO}$ and chloramphenicol served as negative and positive controls, respectively. The MIC was determined by a change in color. The color of each well was compared to those obtained from the negative control. The lowest concentration with the same color as the negative control was interpreted as the MIC (absence of turbidity). All bacterial plates were incubated at $37^{\circ} \mathrm{C}$ for $24 \mathrm{~h}$ while fungal plates were incubated at $28^{\circ} \mathrm{C}$ for $48 \mathrm{~h}$. The colony formation was detected after incubation. The lowest concentration of essential oil sample that was able to effectively reduce the growth of microorganisms (99.5\%) on the agar medium was determined as the MMC.

Flow cytometry. According to the lowest MIC of $P$. dhana essential oil for E. coli, P. aeruginosa, and E. aerogenes strains, the intracellular metabolic activity of these three strains was investigated by measurement of the redox potential using a flow cytometer with a modified method by Girard et al. ${ }^{40}$ Flow cytometric analysis was performed on a DxFLEX Flow Cytometer (BeckmanCoulter Inc., Miami, FL, USA). Data were acquired using light-scatter and fluorescence signals resulting from $15 \mathrm{~mW}$ laser illumination at $488 \mathrm{~nm}$. In total, $1 \mathrm{~mL}$ of Müller-Hinton broth medium was inoculated with bacterial suspension $\left(10^{6} \mathrm{CFU} / \mathrm{mL}\right)$ and supplemented individually with $P$. dhana essential oil, trans-piperitol, $\beta$-pinene, and chloramphenicol at the MIC concentration. A control sample was similarly prepared without any essential oil, standard, or drug. Cytometric analysis was carried out after a $24 \mathrm{~h}$ incubation of the bacteria at $37^{\circ} \mathrm{C}$ with $P$. dhana essential oil, trans-piperitol, $\beta$-pinene, and chloramphenicol. The solution was removed and the probes were centrifuged at $5000 \mathrm{rpm}$ for $5 \mathrm{~min}$. The bacterial pellet was diluted with $250 \mu \mathrm{L}$ of $70 \%$ isopropanol. Cells were stained with $1.5 \mu \mathrm{L}$ of PI and $1.5 \mu \mathrm{L}$ of SYTO9 from a commercial BacLight TM kit (Live/Dead Bacterial viability BacLight TM kit, Thermo Fischer Scientific, Waltham, MA, USA). After 10 min of incubation at room temperature $\left(27^{\circ} \mathrm{C}\right)$ without light, the cells were analyzed. Each sample was analyzed in triplicate. Light-scatter and fluorescence measurements were acquired logarithmically and data were analyzed with CytExpert for DxFLEX software (BeckmanCoulter Inc., Miami, FL, USA). The analysis of the fluorescence signals from both fluorochromes preceded a doublets discrimination procedure using height versus width scatter signals measurement in order to discriminate single events from conglomerates. The populations were then defined by gating in the dot plots of green fluorescence (SYTO9) versus red fluorescence (PI).

Antioxidant activity. DPPH assay. The scavenging capacity against DPPH of the $P$. dhana essential oil was evaluated according to the modified method $^{34}$. The essential oil, trans-piperitol, $\beta$-pinene, and a standard reference, $\mathrm{T}$, were prepared in methanol at the following concentrations: $1000,500,250,125,62.50,31.25,15.62$, and $7.81 \mu \mathrm{g} / \mathrm{mL}$. Two-fold dilution was employed for each mixture. $0.05 \mathrm{~mL}$ of each essential oil and Trolox were mixed with $1.95 \mathrm{~mL}$ of $0.2 \mathrm{~mol} / \mathrm{L}$ methanolic solution of DPPH. The mixture was shaken vigorously and kept in the dark at $27^{\circ} \mathrm{C}$ for $30 \mathrm{~min}$. The absorbance of the mixture was determined at $517 \mathrm{~nm}$ using a PerkinElmer spectrophotometer. Methanol was used as a blank solution. The scavenging capacity was calculated as $\left[\left(\mathrm{A}_{\mathrm{C}}-\mathrm{A}_{\mathrm{s}}\right]\right.$ $\left.A_{c}\right) \times 100$ where $A_{C}$ and $A_{S}$ correspond to the absorbance of the control and sample, respectively. The antioxidant activity of $P$. dhana essential oil and Trolox by $\mathrm{DPPH}$ assay was reported as $\mathrm{IC}_{50}$. Each sample was tested for antioxidant activity in triplicate.

ABTS assay. The scavenging activity against ABTS of the $P$. dhana essential oil was determined according to the modified method ${ }^{34}$. The ABTS radical cation was prepared by mixing $7 \mathrm{mM}$ ABTS solution with $2.45 \mathrm{mM}$ potassium persulfate and kept in the dark at $27^{\circ} \mathrm{C}$. The same concentrations of essential oil, trans-piperitol, $\beta$-pinene, and Trolox were prepared as described in the DPPH assay. For each concentration, $50 \mathrm{~mL}$ of each sample prepared in methanol was mixed with $150 \mathrm{~mL}$ of ABTS radical solution before being shaken vigorously and kept in the dark at $27^{\circ} \mathrm{C}$ for $5 \mathrm{~min}$. The absorbance of the solution was determined at $734 \mathrm{~nm}$ using a UV/ Vis spectrophotometer (PerkinElmer, USA). Methanol was used as a blank solution. Trolox was also used as a standard reference. The scavenging capacity was calculated using the equation described in the DPPH assay. Trolox was used as a standard reference. The antioxidant activity of $P$. dhana essential oil and Trolox by the ABTS assay was also reported as $\mathrm{IC}_{50}$. Each sample was tested for antioxidant activity in triplicate.

In vitro cytotoxicity activity. Cell and culture. The SW480, A549, Hela cells, and 3T3L1 cells were purchased from the China Center for Type Culture Collection. These cells were cultured in Dulbecco's Modified Eagle medium supplemented with $10 \%$ fetal bovine serum and incubated in a humidified incubator at $37^{\circ} \mathrm{C}$ and $5 \% \mathrm{CO}_{2}$ humidified atmosphere in an incubator (Shel lab $\mathrm{CO}_{2}$ Series, USA).

MTT assay. The cytotoxicity of the $P$. dhana essential oil was evaluated by using the MTT reduction inhibition assay $^{38}$. Briefly, the cells were grown in 96 -well culture plates at a density of $1 \times 10^{4}$ cells/well in $1 \mathrm{~mL}$ of fresh medium. After $24 \mathrm{~h}$, cells were treated with different concentrations of essential oil, trans-piperitol, and $\beta$-pinene $(1000,500,250,125,62.50,31.25,15.62$, and $7.81 \mu \mathrm{g} / \mathrm{mL})$ in culture plates. The plates were incubated for $24 \mathrm{~h}$. DMSO treated cells were used as controls. The medium was aspirated, the MTT solution $(10 \mu \mathrm{L}$ of $5 \mathrm{mg} / \mathrm{mL}$ in stock solution) was added to each well, and was further incubated for $4 \mathrm{~h}$. After incubation, $200 \mu \mathrm{L}$ of DMSO was added to dissolve the formed product prior to being placed in a shaking incubator for $10 \mathrm{~min}$. The blue dissolved formazan crystals $(200 \mu \mathrm{L})$ were transferred to a 96-well plate and measured at $570 \mathrm{~nm}$ using a multi-scan 
microplate reader (BioTek Instruments, Inc.). The control consisted of treating cells with DMSO for the same duration of time. Doxorubicin was used as a positive control. The cytotoxic activity of $P$. dhana oil against all cells was reported as $\mathrm{IC}_{50}$ values. The mean $\mathrm{IC}_{50}$ values were calculated by a non-linear regression using version 5.0 of the Graphpad Prism software for Windows (GraphPad Software, USA).

Statistical analysis. Results are expressed as the mean \pm standard deviation (SD). All experiments were performed in triplicate. Analysis of variance (ANOVA) was performed to compare the antimicrobial activities of the $P$. dhana essential oil and its major components. ANOVA was also used to compare the antioxidant activities, and cytotoxic activities of the $P$. dhana essential oil against specific compounds. The mean comparison was based on Student's t-test at $\mathrm{p}<0.05$. All statistical tests were performed using SPSS statistics software (IBM SPSS Statistics for Windows, Version 22.0. Armonk, NY, IBM Corp).

Received: 9 December 2020; Accepted: 6 September 2021

Published online: 27 September 2021

\section{References}

1. Sarkhail, P. Traditional uses, phytochemistry and pharmacological properties of the genus Peucedanum: A review. J. Ethnopharmacol. 156, 235-270 (2014).

2. Smitinand, T. \& Larsen, K. The Forest Herbarium, Royal Forest Department. Flora Thail. 5, 1-470 (1987).

3. Abdollahi, A., Koohpayeh, S. A., Najafpoor, S., Mansoori, Y. \& Abdollahi, S. Evaluation of drug resistance and Staphylococcal cassette chromosome (SCCmec) types among methicillin-resistant Staphylococcus aureus (MRSA). J. Alborz Health 1, 47-52 (2013).

4. Motskute, D. \& Nivinskene, O. Essential oil of Peucedanum oreoselinum fruits collected near Vilnius. Chem. Nat. Compd. 35, 635-637 (1999).

5. Dobaria, J. D., Mandavia, M. K., Patel, S. V. \& Golakiya, B. A. Separation of secondary metabolites from Peucedanum dhana (Bhojraj), a rare herb. Indian J. Agric. Biochem. 26, 160-166 (2013).

6. Mostaph, M. K. \& Uddin, S.B. Dictionary of Plant Names of Bangladesh, Vasc. Pl. 1-434. (Janokalyan Prokashani, 2013).

7. Kumar, S. Herbaceous flora of Jaunsar-Bawar (Uttarkhand), India: Enumerations. Phytotaxonomy 12, 33-56 (2012).

8. Kress, W. J., DeFilipps, R. A., Farr, E. \& Kyi, D. Y. Y. A Checklist of the Trees, shrubs, herbs and climbers of Myanmar contributions from the United States National Herbarium. Smithson. Inst. 45, 1-590 (2003).

9. Shukla, R., Chakravarty, M. \& Gautam, M. P. Indigenous medicine used for treatment of gynecological disorders by tribal of Chhattisgarh. J. Med. Plant Res. 2, 356 (2008).

10. Adams, R. P. Identification of Essential Oil Components by Gas Chromatography/Mass Spectroscopy, 4.1 Ed. (Allured Publishing Corporation, 2017).

11. Babushok, V. I., Linstrom, P. J. \& Zenkevich, I. G. Retention indices for frequently reported compounds of plant essential oils. J. Phys. Chem. Ref. Data 40, 043101 (2011).

12. Ilić, B., Miladinović, D., Kocić, B. \& Miladinović, M. Antibacterial profile of Peucedanum longifolium essential oil. Acta Med. Mediterr. 54, 20-26 (2015).

13. Alavi, S. H. R., Yassa, N. \& Fazeli, M. R. Chemical constituents and antibacterial activity of essential oil of Peucedanum ruthenicum M. Bieb. fruits. Iran. J. Pharm. Sci. 1, 217-222 (2005).

14. Cisowski, W., Sawicka, U., Mardarowiczb, M., Asztemborskac, M. \& Łuczkiewiczd, M. Essential oil from herb and rhizome of Peucedanum ostruthium (L. Koch) ex DC. Z. Naturforsch 56, 930-932 (2001).

15. Vellutini, M., Baldovini, N., de Rocca Serra, D., Tomi, F. \& Casanova, J. $\beta$-Cyclolavandulyl and $\beta$-isocyclolavandulyl esters from Peucedanum paniculatum L., an endemic species to Corsica. Phytochemistry 66, 1956-1962 (2005).

16. Figuérédo, G. et al. Composition of essential oils of flowers, leaves, stems and rhizome of Peucedanum officinale L. (Apiaceae). J. Essent. Oil Res. 21, 123-126 (2009).

17. Syed, M., Sabir, A. W., Chaudhary, F. M. \& Bhatty, M. K. Antimicrobial activity of essential oils of umbelliferae family part vii. Heracleum candicans Pragos pabularia and Peucedanum ferulaefolium fruit oil. Pak. J. Sci. Ind. Res. 31, 557-560 (1988).

18. Alavi, S. H. R. et al. The chemical constituents and antibacterial activity of essential oil of Peucedanum ruthenicum (M. Bieb.) rochel (Umbelliferae) leaf. J. Med. Plant Res. 6, 33-38 (2007).

19. Yang, E. J. et al. Peucedanum japonicum and Citrus unshiu essential oils inhibit the growth of antibiotic-resistant skin pathogens. Ann. Microbiol. 59, 623 (2009).

20. Skalicka-Woźniak, K., Los, R., Głowniak, K. \& Malm, A. Antimicrobial activity of fatty acids from fruits of Peucedanum cervaria and P. alsaticum. Chem. Biodivers. 7, 2748-2754 (2010).

21. Pirbalouti, A. G., Mahdad, E. \& Craker, L. Effects of drying methods on qualitative and quantitative properties of essential oil of two basil landraces. Food Chem. 141, 2440-2449 (2013).

22. Burt, S. Essential oils: Their antibacterial properties and potential applications in foods-a review. Int. J. Food Microbiol. 94, 223-253 (2004).

23. Sutour, S., Tomi, F., Bradesi, P. \& Casanova, J. Chemical composition of the essential oil from Corsican Mentha aquatica-combined analysis by GC (RI), GC-MS and ${ }^{13} \mathrm{C}$ NMR spectroscopy. Nat. Prod. Commun. 6, 1479-1482 (2011).

24. Bassole, I. H. N. et al. Composition and antimicrobial activities of the leaf and flower essential oils of Lippia chevalieri and Ocimum canum from Burkina Faso. Afr. J. Biotechnol. 4, 1156-1160 (2005).

25. Utegenova, G. A. et al. Chemical composition and antibacterial activity of essential oils from Ferula L. species against methicillinresistant Staphylococcus aureus. Molecules 23, 1679 (2018).

26. Dorman, H. D. \& Deans, S. G. Antimicrobial agents from plants: Antibacterial activity of plant volatile oils. J. Appl. Microbiol. 88, $308-316(2000)$.

27. Mahboubi, M. \& Kazempour, N. Chemical composition and antimicrobial activity of Satureja hortensis and Trachyspermum copticum essential oil. Iran J. Microbiol. 3, 194-200 (2011).

28. Taghizadeh, S. F. et al. Chemical composition, antibacterial, antioxidant and cytotoxic evaluation of the essential oil from pistachio (Pistacia khinjuk) hull. Microb. Pathog. 124, 76-81 (2018).

29. Moleyar, V. \& Narasimtram, P. Antifungal activity of some essential oil components. Food Microbiol. 3, 331-336 (1996).

30. Velkov, T., Roberts, K. D., Nation, R. L., Thompson, P. E. \& Li, J. Pharmacology of polymyxins: New insights into an 'old' class of antibiotics. Future Microbiol. 8, 711-724 (2013).

31. Gourine, N. et al. Antioxidant activities and chemical composition of essential oil of Pistacia atlantica from Algeria. Ind. Crops Prod. 31, 203-208 (2009).

32. Tepe, B., Degerli, S., Arslan, S., Malatyali, E. \& Sarikurkcu, C. Determination of chemical profile, antioxidant, DNA damage protection and antiamoebic activities of Teucrium polium and Stachys iberica. Fitoterapia 82, 237-246 (2011).

33. Salehi, B. et al. Therapeutic potential of $\alpha$-and $\beta$-pinene: A miracle gift of nature. Biomolecules 9,738 (2019). 
34. Sharopov, F. S., Wink, M. \& Setzer, W. N. Radical scavenging and antioxidant activities of essential oil components-An experimental and computational investigation. Nat. Prod. Commun. 10, 1934578X1501000135 (2015).

35. Sylvestre, M., Pichette, A., Longtin, A., Nagau, F. \& Legault, J. Essential oil analysis and anticancer activity of leaf essential oil of Croton flavens L. from Guadeloupe. J. Ethnopharmacol. 103, 99-102 (2006).

36. Koba, S., Gao, Z. \& Sinoway, L. I. Oxidative stress and the muscle reflex in heart failure. J. Physiol. 587, 5227-5237 (2009).

37. Döll-Boscardin, P. M. et al. In vitro cytotoxic potential of essential oils of Eucalyptus benthamii and its related terpenes on tumor cell lines. Evid. Based Complement. Altern. Med. 2012, 342652 (2012).

38. Cannas, S. et al. Chemical composition, cytotoxicity, antimicrobial and antifungal activity of several essential oils. Nat. Prod. Res. 30, 332-339 (2016).

39. Yeong, M. Y. et al. Data on cytotoxicity of plant essential oils in A549 and Detroit 551 cells. Data Brief 32, 106-186 (2020).

40. Girard, C., Fayolle, K., Kerros, S. \& Leriche, F. Flow cytometric assessment of the antimicrobial properties of an essential oil mixture against Escherichia coli. J. Anim. Feed Sci. 28, 187-198 (2019).

\section{Acknowledgements}

We would like to thank Mae Fah Luang University and the Royal Golden Jubilee Ph.D. Programme for financial support through Grant no. PHD/0193/2560.

\section{Author contributions}

S.K., T.S., and N.R. performed experiments. S.K. performed GC-MS analysis, analyzed data, and wrote the first draft of the manuscript. R.C. and P.P. performed flow cytometric analysis and reviewed the manuscript. P.P. supervised the work.

\section{Funding}

Funding was funded by Thailand Research Fund (Grant no: RGJPHD0193/2560) and Mae Fah Luang University.

\section{Competing interests}

The authors declare no competing interests.

Additional information

Correspondence and requests for materials should be addressed to P.P.

Reprints and permissions information is available at www.nature.com/reprints.

Publisher's note Springer Nature remains neutral with regard to jurisdictional claims in published maps and institutional affiliations.

(c) (i) Open Access This article is licensed under a Creative Commons Attribution 4.0 International License, which permits use, sharing, adaptation, distribution and reproduction in any medium or format, as long as you give appropriate credit to the original author(s) and the source, provide a link to the Creative Commons licence, and indicate if changes were made. The images or other third party material in this article are included in the article's Creative Commons licence, unless indicated otherwise in a credit line to the material. If material is not included in the article's Creative Commons licence and your intended use is not permitted by statutory regulation or exceeds the permitted use, you will need to obtain permission directly from the copyright holder. To view a copy of this licence, visit http://creativecommons.org/licenses/by/4.0/.

(c) The Author(s) 2021 